\title{
CARBON DUST IN PRIMARY COOLANT OF RDE: ITS PROBLEM AND SOLUTION
}

\author{
Sriyono, Topan Setiadipura, Geni R. Sunaryo \\ Center for Nuclear Reactor Technology and Safety, BATAN, Gedung 80, Kawasan Puspiptek, Serpong, \\ Tangerang Selatan, BANTEN, Telp.: 62-21-7560912, Fax.: 62-21-7560913, ZIP Code : 15310
}

Email: sriyono@batan.go.id

Diterima editor: 19 Juli 2018

Diperbaiki: 26 Juli 2018

Disetujui untuk publikasi: 31 Juli 2018

\begin{abstract}
CARBON DUST IN PRIMARY COOLANT OF RDE: ITS PROBLEM AND SOLUTION. There are two kinds of impurities in primary coolant of Reaktor Daya Eksperimental (RDE) i.e. gaseous and particulate impurities. Carbon dust as a particulate impurity is generated from abrasion of pebble friction in the core and friction between pebble and refueling pipelines. Due to negative impact to the system, structure and component (SCC), therefore carbon dust must be removed from primary coolant. This paper discusses the carbon dust removal in RDE. The objected of the research is to analyze the helium purification system (HPS) capability of removing carbon dust through particle size distribution analysis. The carbon dust size particle varies from $0.1 \mu \mathrm{m}$ up to $10 \mu \mathrm{m}$ regarding to the experiences of high temperature gas cooled reactor (HTGR) operation. Three models have been made by using ChemCAD. First model was using single filter, second model was using 2 filters in series and the last one was using both double filters in series and cyclone. The dust removal total efficiency of first model is $88.70 \%$, the second model is $98.10 \%$ and the last one is $98.89 \%$. The highest efficiency of $98.98 \%$ was achieved in the model that used both double filters and cyclone. The cyclone should be installed in HPS of RDE if there are coarse carbon dust particle, which was found in the primary coolant to increase its dust removal capability.
\end{abstract}

Keywords: Carbon dust problem, primary coolant, particle size distribution, RDE

\begin{abstract}
ABSTRAK
DEBU KARBON PADA PENDINGIN PRIMER RDE: PERMASALAHAN DAN SOLUSINYA. Ada dua jenis pengotor pada pendingin primer RDE yaitu pengotor berbentuk gas dan partikel padat. Debu karbon adalah salah satu pengotor berbentuk partikel padat. Debu ini dihasilkan dari gesekan antara bahan bakar di teras dan gesekan antara bahan bakar dengan pipa pengisian bahan bakar. Karena berdampak negatif terhadap sistem, struktur dan komponen (SSK), maka debu karbon tersebut harus dibersihkan dari pendingin primer. Makalah ini membahas proses pembersihan debu karbon pada pendingin RDE. Tujuan penelitian ini adalah untuk memahami kemampuan sistem pemurnian helium (SPH) dari RDE dalam menghilangkan debu karbon melalui analisis distribusi ukuran partikel. Ukuran distribusi debu karbon divariasikan dari 0,1 $\mu$ m sampai dengan $10 \mu \mathrm{m}$ berdasarkan pengalaman operasi HTGR. Tiga model telah dibuat menggunakan perangkat lunak ChemCAD. Model pertama menggunakan filter tunggal, model kedua menggunakan 2 filter yang disusun secara serial dan yang ketiga adalah model menggunakan 2 filter dan cyclone. Efisiensi total pembersihan debu karbon dari model yang pertama $88,70 \%$, model yang kedua adalah $98,10 \%$ and model yang terakhir adalah 98,89\%. Efisiensi pembersihan debu karbon tertinggi yaitu 98,98\% diperoleh pada model yang menggunakan 2 filter dan cyclone. Untuk meningkatkan kemampuan pembersihan debu karbon, desain SPH RDE perlu ditambahkan cyclone jika ditemukan partikel debu karbon kasar pada saat beroperasi.
\end{abstract}

Kata kunci: permasalahan debu karbon, pendingin primer RDE, distribusi ukuran partikel

DOI: $10.17146 / t d m .2018 .20 .2 .4456$ 


\section{INTRODUCTION}

Batan is purposing to design an experimental power reactor which called Reaktor Daya Eksperimental (RDE). It is designed based on High Temperature Gas Cooled Reactor (HTGR) technology, an indirect cycle with helium as primary coolant and water as secondary coolant [1]. $\mathrm{RDE}$ uses graphite as moderator and reflector, and pebble as fuel. The primary coolant flows in the fuel gap from the bottom to the upper side of the reactor core. Helium is chemically inert gas and it is thermally stable at high temperatures and under irradiation reactor operation conditions [2]. The heat from the core is transferred to the secondary coolant through steam generator (SG). The RDE is designed to generate electricity, but it can also be used to support hydrogen production process, the coal gasification/liquefaction and desalination [3].

Helium purification system (HPS) is an important system in RDE. This system removes impurities contained in primary helium cooling system [4]. There are two kinds of impurities i.e. particulates and gaseous ones [4]. The particulates impurities are graphite dust and fission products released from the reactor core, and the gaseous impurities are $\mathrm{N}_{2}, \mathrm{O}_{2}, \mathrm{H}_{2}, \mathrm{O}_{2}, \mathrm{CH}_{4}, \mathrm{CO}, \mathrm{H}_{2} \mathrm{O}$ and $\mathrm{CO}_{2}[2,5,6]$. The purity of helium in primary coolant must be maintained according to its design limit. Carbon dust particle in the helium is important issue to solve in the RDE. The dust is generated by several mechanisms, including abrasion from pebble friction in the core, friction between fuel elements and pipelines of fuel element cycle, organic compound (lubricants) remaining during maintenance outage $[7,8]$. The dust in primary system impacts on the decrease of heat transfer capacity and carbon dust carries fission product and, hence, it increases radiation exposure [6]. The carbon dust, which is strongly adhered to the high temperature pipeline and contained of fission product, is danger to the worker and environment, therefore must be removed [9].

Some literatures indicate the presence of carbon dust during the pebble reactor operates. AVR produces $20 \mathrm{~kg}$ of carbon dust at the end of its operation [8], HTR-10 generates $2.74 \mathrm{~kg}$ per year of carbon dust [9], and Japanese HTTR is $2.5 \mathrm{~kg}$ per year. The prismatic HTGR has less of dust comparing to pebble [10]. The carbon dust generation depends on the fuel type (prismatic or pebble), power conversion system (direct or indirect cycle), and refueling method (multi-pass, OTTO etc.) $[8,10]$. The dust safety issues in HTGRs proves that the dust related research was urgently needed for the development of pebble bed HTGRs on topics such as the dust distribution under normal operation, dust generation, dust-fission product interaction, etc. [11]. Therefore this paper discusses the dust filter capability in HPS to remove carbon dust from primary coolant of RDE.

Helium Purification System (HPS) is responsible for maintaining the purity of primary coolant of RDE. The RDE has one train used during normal operations and accidents [4]. The ChemCAD (Chemical Computer Aided Design) computer code is used to simulate that process. This software can be used to simulate the process modeling in various industries [12]. Several papers have been published regarding the behavior of dust in HTGRs, including the generation, characterization, transport, coagulation, aggregation, deposition, resuspension, etc. [10, 13]. The objected of this research is to analyze the helium purification system (HPS) capability of removing carbon dust through particle size distribution analysis. Based on HTGR operating experiences the amount and size distribution of carbon dust in primary coolant cannot determined exactly [7]. AVR has been operated for 21 years (1967-1988) in Germany, every pebble estimated produce carbon dust rate at $0.015 \sim 0.03$ grams per year [7]. Regarding its design; RDE has $\sim 27,000$ pebble balls in the core so it is assumed that it generates $0.046-0.092 \mathrm{~kg}$ of carbon dust. The dust particles size varies from $0.1 \mu \mathrm{m}$ to $10 \mu \mathrm{m}$. When dispersed in a gas, the nominally $\mu \mathrm{m}$-sized dust particles constitute an aerosol [8]. The size distribution of AVR dust has been measured and was found to largely contain submicron particles with a mean diameter of $0.6 \mu \mathrm{m}$, corresponding to a volumeweighted mean of 5 to $10 \mu \mathrm{m}$ [10]. Three scenario models have been proposed and simulated by using ChemCAD. This software is an integrated suite of chemical process simulation that fits into the chemical engineering workflow. First model was using single filter, second model was using 2 filters in series and the last one was using both double filters in series and cyclone. First and second filter has $3.0 \mu \mathrm{m}$ and $1.0 \mu \mathrm{m}$ of porosity diameter and the cyclone that used is a high efficiency 
type. The inlet stream (input) is defined as helium with dust particles contained, and it will be separated by both filters and cyclone. The carbon dust separation result is evaluated by its particles distribution in the inlet and outlet of each model. By simulating of each model the removal of carbon dust capability will be determined.

\section{THEORY}

\section{Helium Purification System (HPS) Description}

RDE has one train of HPS. The extraction line in the primary circuit is shown in Figure 1. HPS extracts the helium from the discharge of primary gas blower, which is in the steam generator vessel pressure, and the purified helium returns to the suction of the main gas blower [14]. Extracting helium on this location continuously remove contaminants in the case of significant impurities ingress such as water/air ingress. During steam generator tube rupture (SGTR) accident, water will leak to the primary circuit and by pulling a significant quantity of the bypass flow from this location, it can remove a significant amount of moisture before it reaches reactor core. The positive reactivity and graphite oxidation can be anticipated. The HPS and it supporting systems fulfill the following functions i.e. to remove chemical and particulate contaminants from the primary coolant to maintain specified values, to supply purified helium to systems filled with helium, to remove helium from the primary system and the helium filled supporting systems and storage in the purified gas store, to relieve pressure and dumping helium from helium filled auxiliary and supporting systems and, to possibly store radioactively contaminated helium, and evacuation of primary systems and helium supporting systems [3].

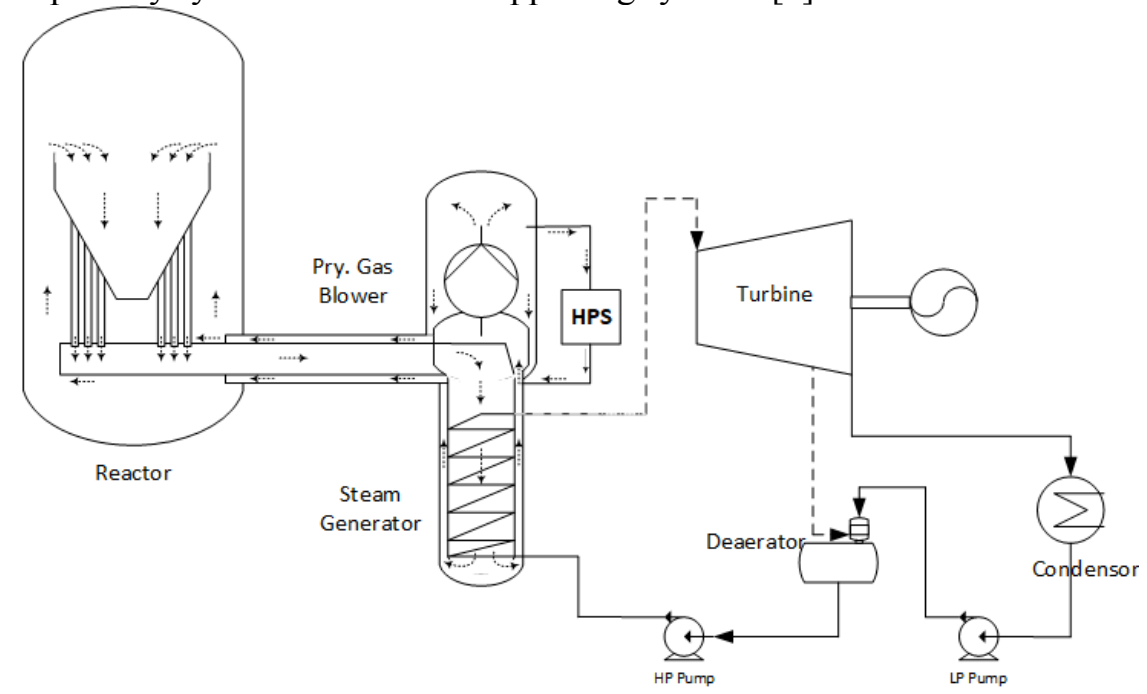

Figure 1. The primary circuit of RDE and HPS extraction point [3].

HPS as seen at Figure 2 has a single train including for normal and accident operation. During normal operation, it uses main line. The main line has several important components such as graphite dust filter, copper oxide bed, condenser, water trap, molecular sieve adsorber, and cryogenic unit. It uses different line during water ingress accident. The components for accident condition are dust filter, condenser, water separator and blower. In the normal operation, dust filter removes carbon dust, copper oxide bed converts $\mathrm{H}_{2}$ to $\mathrm{H}_{2} \mathrm{O}$, tritium to $\mathrm{HTO}$ (tritiated water) and $\mathrm{CO}$ to $\mathrm{CO}_{2}$, molecular sieve adsorbed the $\mathrm{CO}_{2}, \mathrm{CH}_{4}, \mathrm{HTO}$, and $\mathrm{H}_{2} \mathrm{O}$, and cryogenic unit adsorbed $\mathrm{N}_{2}, \mathrm{H}_{2}$, tritium, and fission products (Ar, Kr, Cs, etc.) [13]. The regeneration of the HPS is done during reactor shutdown or annual maintenance.

The mass flow rate is determined by purification constant, which shows a coolant mass fraction purified per hour. The bypass flow to be purified is approximately $10.5 \mathrm{~kg} / \mathrm{h}$ during the 
normal operation or the hourly ratio of the extracted helium gas to the helium inventory in the primary circuit is about $5 \%$, equivalent to a purification constant of $0.05 \mathrm{~h}^{-1}$. The HPS inlet temperature is about $200-240^{\circ} \mathrm{C}$. Copper oxide bed optimum temperature absorption process is 250 ${ }^{\circ} \mathrm{C}$ hence electrical heater is needed to install before that column. The electric heater which follows raises the temperature of the helium to approx. $250{ }^{\circ} \mathrm{C}$, if necessary, so that purification can take place even primary circuit is cooled down. The outlet of copper bed is $\mathrm{CO}_{2}$ and $\mathrm{H}_{2} \mathrm{O}$, water cooler and water separator is installed to remove $\mathrm{H}_{2} \mathrm{O}$, HTO and then molecular sieve adsorbed $\mathrm{CO}_{2}$. The cryogenic unit contained charcoal active adsorber and liquid nitrogen supplied system. Charcoal active bed is surrounded by liquid nitrogen in the very low temperature of $-190{ }^{\circ} \mathrm{C}$, hence $\mathrm{N}_{2}, \mathrm{H}_{2}$ and other noble gas from fission products such as $\mathrm{Ar}, \mathrm{Xe}, \mathrm{Kr}$ etc., easily trap in cryogenic system [15]. The HPS can be operated for 1000 hours before regeneration process.

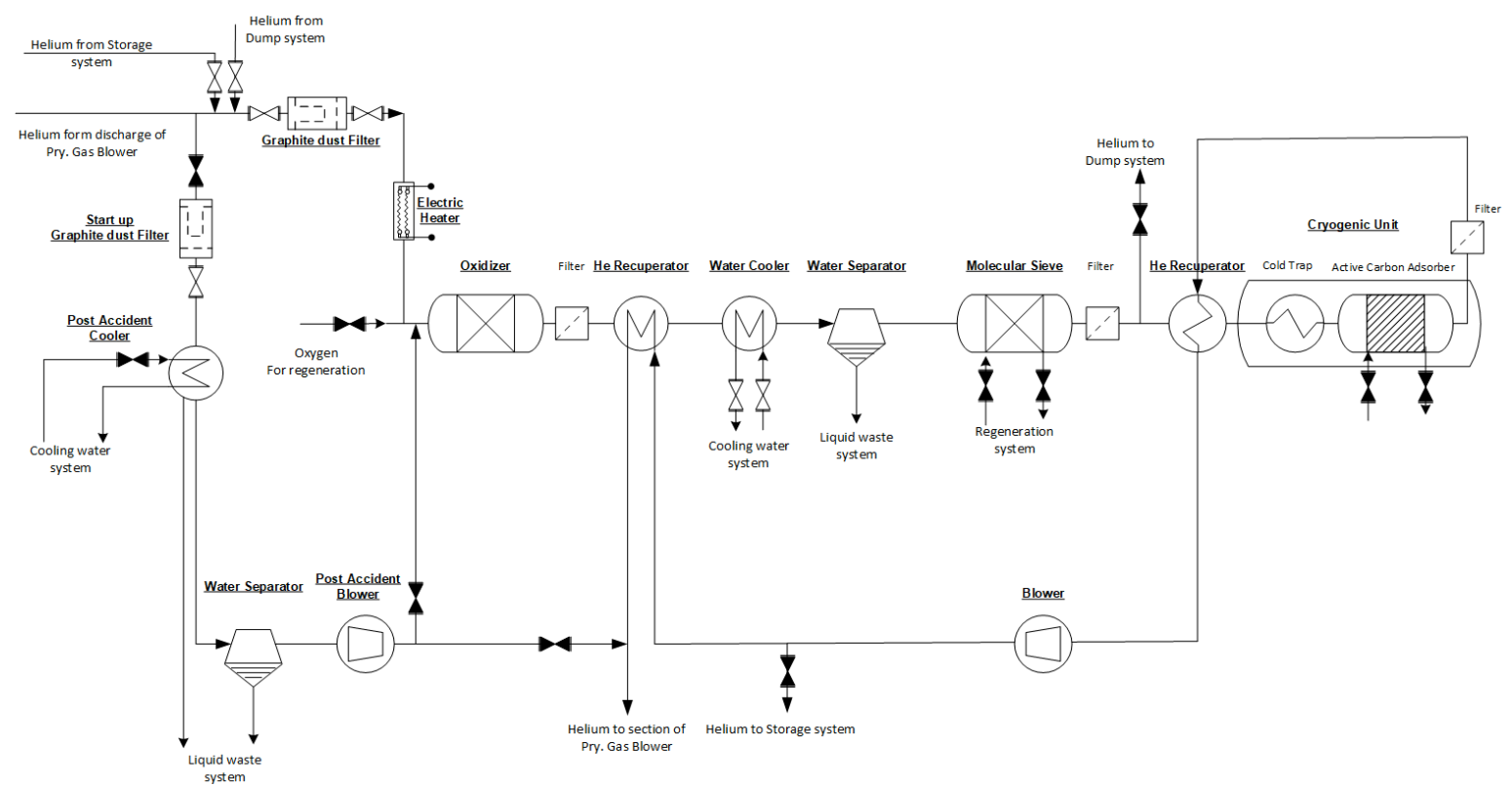

Figure 2. Helium purification train of RDE [3]

\section{METHODOLOGY}

The carbon dust filtration is modeled by ChemCAD. The bag house filter is selected to represent cartridge filter. The bag house filter module simulates or rates the operation of a standard fabric filter dust collector. The HPS inlet mass flow rate is $10.5 \mathrm{~kg}$ per hour, $240{ }^{\circ} \mathrm{C}$ of temperature and 30 bar of pressure. The technical specification of HPS is shown in Table 1.

Table 1. The RDE parameter for HPS modeling $[1,16,17]$

\begin{tabular}{|c|c|c|c|}
\hline No. & Parameters & Unit & Value \\
\hline 1. & Reactor thermal power & MW & 10 \\
\hline 2. & Primary coolant pressure (helium) & $\mathrm{MPa}$ & 3 \\
\hline 3. & Reactor core inlet temperature & ${ }^{\circ} \mathrm{C}$ & 250 \\
\hline 4. & Reactor core inlet temperature & ${ }^{\circ} \mathrm{C}$ & 700 \\
\hline 5. & Primary coolant mass flow rate & $\mathrm{kg} / \mathrm{s}$ & 4.27 \\
\hline 6. & Feed water temperature (secondary coolant) & ${ }^{\circ} \mathrm{C}$ & 104 \\
\hline 7. & Steam temperature (secondary coolant) & ${ }^{\circ} \mathrm{C}$ & 530 \\
\hline 8. & Primary blower pressure & bar & 30 \\
\hline 9. & Primary blower/compressor temperature & ${ }^{\circ} \mathrm{C}$ & 250 \\
\hline 10. & HPS bypass flow from primary coolant & $\%$ & 5 \\
\hline 11. & Helium gas impurities & & $\begin{array}{l}\mathrm{CO}, \mathrm{H}_{2} \mathrm{O}, \mathrm{CO}_{2}, \mathrm{~N}_{2}, \mathrm{CH}_{4}, \mathrm{H}_{2} \text {, } \\
\mathrm{HTO}, \mathrm{O}_{2} \text {, and noble gas (Xe, } \\
\mathrm{Kr} \text {, Ar etc.) }\end{array}$ \\
\hline
\end{tabular}


The values of carbon dust size distribution in AVR operating experiences was used to simulated in the inlet stream of HPS as seen in Table 2. The filter modeled is seen in Figures 3, 4 and 5. To optimize carbon dust removal on HPS is simulated by constructing 3 scenarios. The first model is HPS using one filter (Figure 3), the second model is installed 2 filters (double) in series with different porosity (Figure 4), and the third one is a model with the addition of cyclone before the double filters (Figure 5). Two filters mounted in series (F1 and F2). First filter has porosity of 3 $\mu \mathrm{m}$ and the second has $1 \mu \mathrm{m}$ to eliminate the fine carbon dust that still passes from F1. Cyclone is installed as a coarse carbon dust separation in the early stage of HPS. Stream no. 1 is main primary coolant flow, stream no. 3 is bypass flow from main primary coolant to HPS (5\% of main primary coolant), stream no. 4 , no. 7 , and no. 9 is separated carbon dust stream (solid waste stream), and stream no. 5 , no. 6, no. 8 is purified helium.

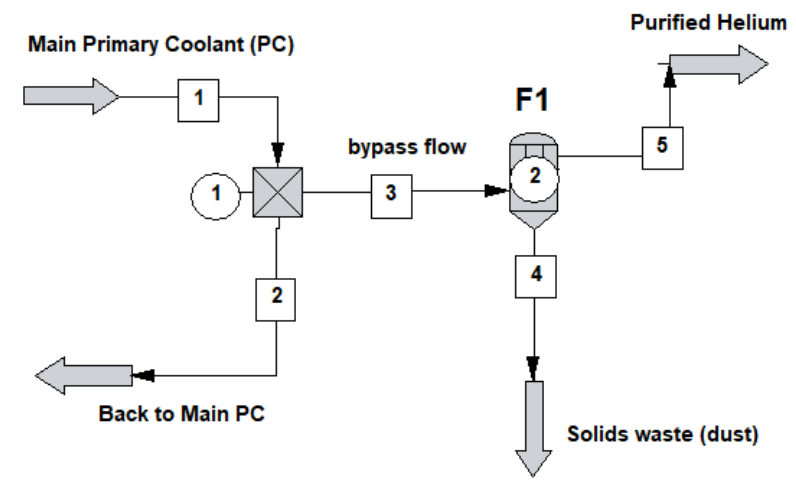

Figure 3. The HPS modelling with a single filter

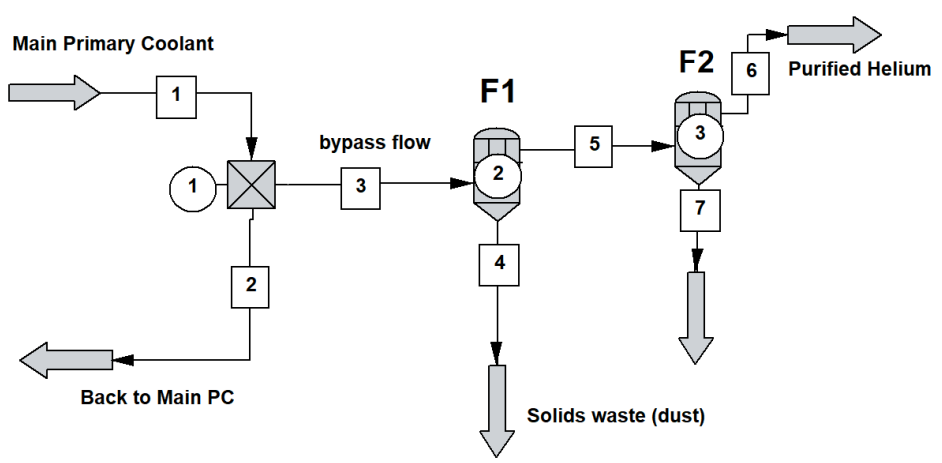

Figure 4. The HPS modelling with double filter in series

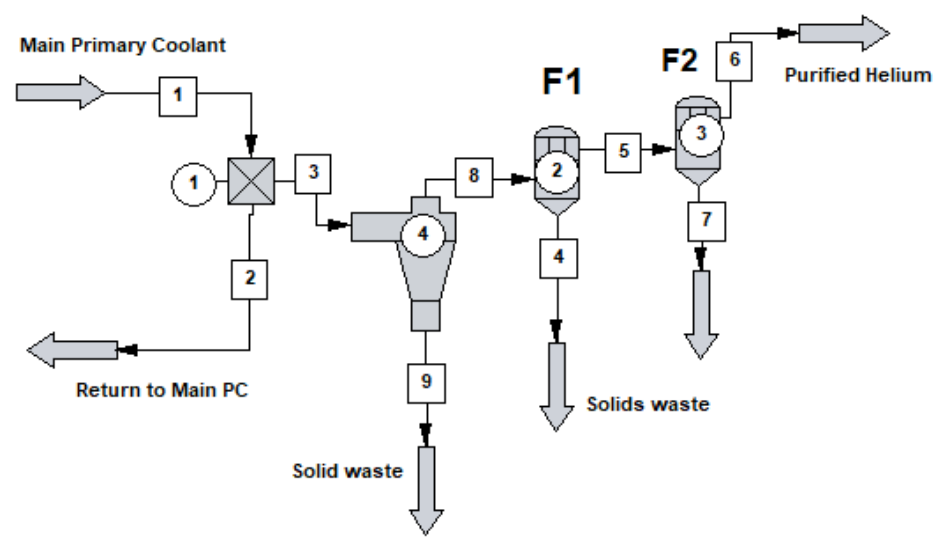

Figure 5. The HPS modeling with double filters and cyclone 


\section{RESULT AND DISCUSSION}

The particulate impurities in primary coolant of RDE must be cleaned due to its negative impact to SCC. Carbon dust release from the core and carries some fission product dangerous to environment and workers. The cleaning process is done by filtration uses cartridge or HEPA filter. The cartridge filter porosity size is chosen depend on the dust particle size must be removed. To determine the filter capability, the particle distribution from the inlet and outlet stream is analyzed. Dust composition and its particles size distribution in primary coolant of RDE is shown in Table 2. In the main primary coolant is assumed that almost $50 \%$ of dust size is smaller than $3 \mu \mathrm{m}$. The pebble fuel density is assumed strongly enough to keep the integrity of its surface so dust generation is minimized.

Table 2. Carbon dust particle size distribution in main primary coolant

\begin{tabular}{cc}
\hline Dust size $(\mu \mathrm{m})$ & Weight fraction \\
\hline 1.00 & 0.18919 \\
2.00 & 0.13514 \\
3.00 & 0.13514 \\
5.00 & 0.13514 \\
6.00 & 0.13514 \\
7.00 & 0.13514 \\
10.00 & 0.13514 \\
\hline
\end{tabular}

The simulation using single filter of $3 \mu \mathrm{m}$ (as seen in Figure 3 ) has been done. By using this filter almost of $88.12 \%$ of dust was removed from $0.0046 \mathrm{~kg} / \mathrm{h}$ in the inlet (stream no.3) to 0.00053 $\mathrm{kg} / \mathrm{h}$ in the outlet of filter (stream no.5). The dust particle size distribution in the inlet and outlet of filter is shown in Table 3 and Figure 6. In clean outlet of filter (stream no.5) is dominated by small dust lower than $0.3 \mu \mathrm{m}$ of size. It is about $17.88 \%$ of total dust was still remaining in the HPS flow. This fine dust still need to be clean and should not exist in the primary coolant.

Table 3. Particle size distribution in the inlet and outlet of cartridge filter F1

\begin{tabular}{cccc}
\hline \multirow{2}{*}{ Parameters } & Inlet F1 & \multicolumn{2}{c}{ Outlet F1 } \\
\cline { 2 - 4 } & $\begin{array}{c}\text { Dirty stream } \\
\text { (stream no. 3) }\end{array}$ & $\begin{array}{c}\text { Removed } \\
\text { (stream no.4) }\end{array}$ & $\begin{array}{c}\text { Remains } \\
\text { (stream no.5) }\end{array}$ \\
\hline Mass flow rate $(\mathrm{kg} / \mathrm{h})$ & 0.0046 & 0.0040 & 0.00053 \\
\hline Dust size (um) & Particle size distribution (weight fraction) & (stream no.5) \\
\hline 1.00 & (stream no. 3) & (stream no.4) & 0.41081 \\
2.00 & 0.18919 & 0.16035 & 0.18874 \\
3.00 & 0.13514 & 0.12816 & 0.13464 \\
5.00 & 0.13514 & 0.13520 & 0.08792 \\
6.00 & 0.13514 & 0.14128 & 0.07422 \\
7.00 & 0.13514 & 0.14306 & 0.06334 \\
10.00 & 0.13514 & 0.14448 & 0.04032 \\
\hline
\end{tabular}




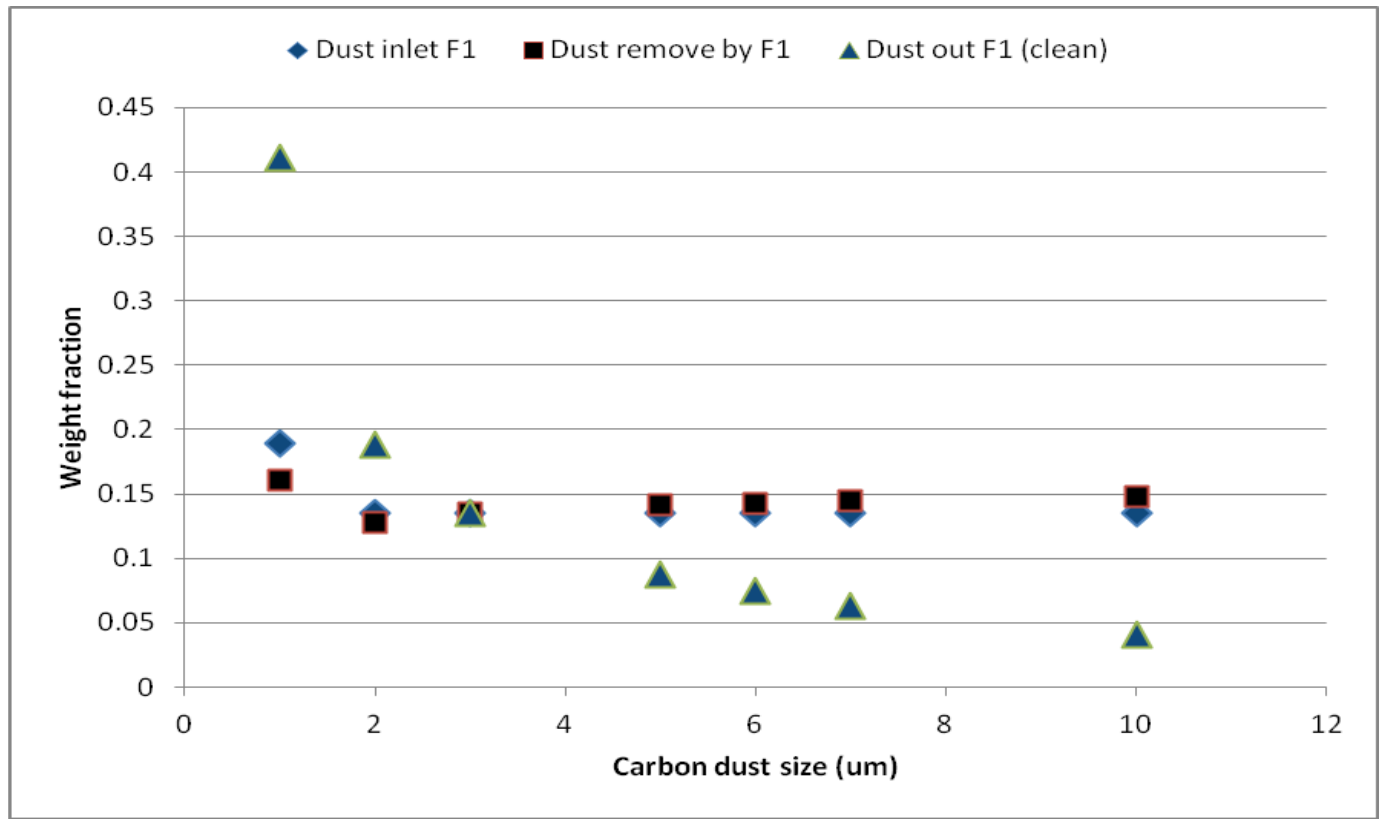

Figure 6. Particle size distribution in the inlet and outlet of cartridge filter F1

Smaller filter porosity is installed to remove remaining carbon dust (as seen in Figure 4). The filter porosity of $\mathrm{F} 2$ is $1.0 \mu \mathrm{m}$. The dust particle size distribution from the inlet and outlet of F2 is seen in Table 4 and Figure 7. In F2, 88.53\% of fine carbon dust was removed from $0.00053 \mathrm{~kg} / \mathrm{h}$ (stream no.5) to $0.000087 \mathrm{~kg} / \mathrm{h}$ (stream no.7). In the simulation using double filters (F1 and F2) $98.10 \%$ of carbon dust was removed. It is clear that uses two filters in series more advantage comparing to single filter. HPS using 2 or more filters can prevent filter blockage easily. It is assumed that changes occurring in filter structure due to deposition of particles are sufficiently negligible so that filter efficiency is unaffected. Particles making contact with a filter fiber are captured without modification of filtration mechanisms. During this 'stationary phase', $\mathrm{P}$ (pressure) and $\Delta \mathrm{P}$ (pressure drop) in the stream do not change with time. Thus the filter life can be longer and able to reduce reactor operating costs.

Table 4. Particle size distribution of inlet and outlet of cartridge filter F2

\begin{tabular}{|c|c|c|c|}
\hline \multirow[b]{2}{*}{ Parameters } & Inlet F2 & \multicolumn{2}{|c|}{ Outlet F2 } \\
\hline & $\begin{array}{c}\text { Outlet F1 } \\
\text { (stream no. 5) }\end{array}$ & $\begin{array}{c}\text { Removed } \\
\text { (stream no.6) }\end{array}$ & $\begin{array}{c}\text { Remains/clean stream } \\
\text { (stream no.7) }\end{array}$ \\
\hline $\begin{array}{l}\text { Mass flow rate } \\
(\mathrm{kg} / \mathrm{h})\end{array}$ & 0.00053 & 0.00044 & 0.000087 \\
\hline \multicolumn{4}{|c|}{ Particle size distribution (weight fraction) } \\
\hline Dust size $(\mu \mathrm{m})$ & (stream no. 5) & (stream no.6) & (stream no.7) \\
\hline 1.00 & 0.41081 & 0.62402 & 0.36880 \\
\hline 2.00 & 0.18874 & 0.18441 & 0.18959 \\
\hline 3.00 & 0.13464 & 0.09385 & 0.14268 \\
\hline 5.00 & 0.08792 & 0.04002 & 0.09736 \\
\hline 6.00 & 0.07422 & 0.02852 & 0.08322 \\
\hline 7.00 & 0.06334 & 0.02077 & 0.07173 \\
\hline 10.00 & 0.04032 & 0.00842 & 0.04660 \\
\hline
\end{tabular}




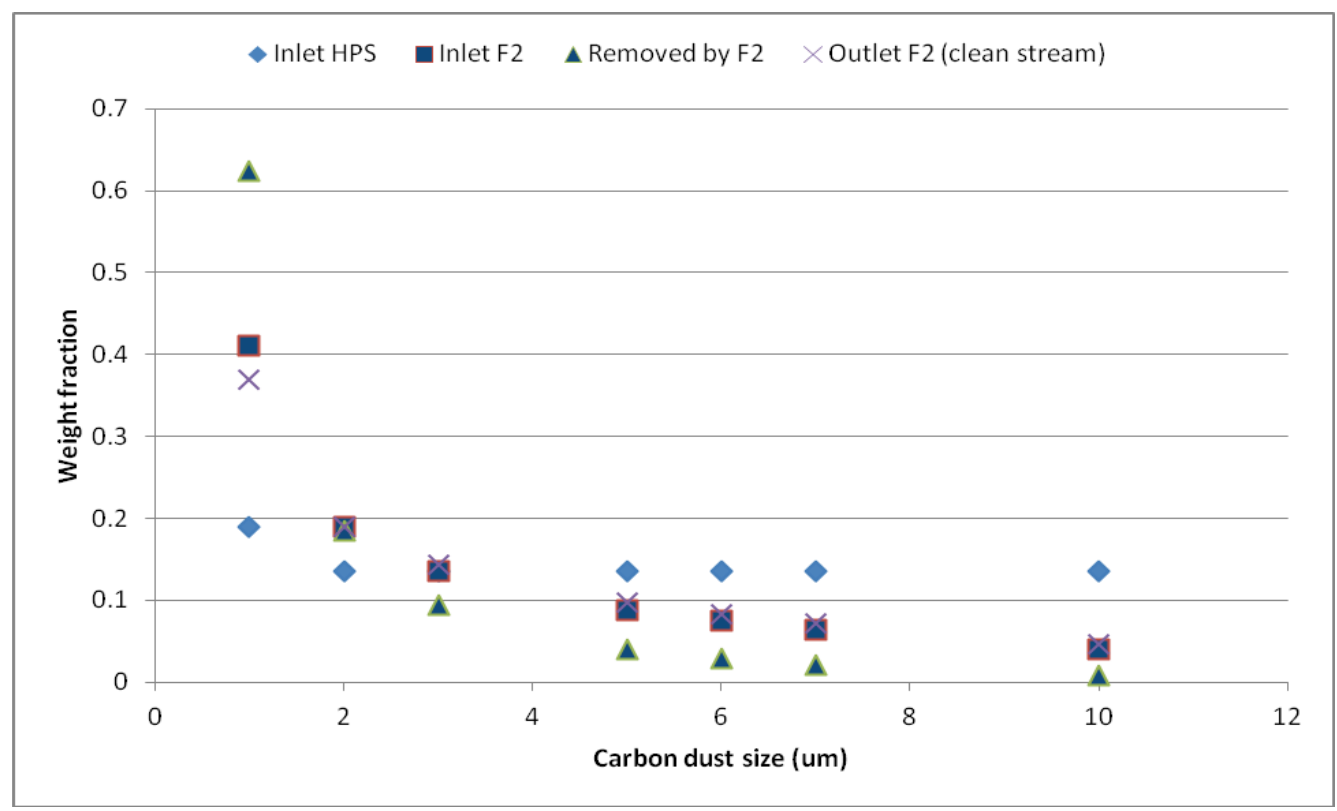

Figure 7. Particle size distribution in the inlet and outlet of cartridge filter F2

Carbon dust simulation uses cyclone separator (CS) which installed in first stage of HPS is seen in Figure 5. Cyclone is a mechanical separator using centrifugal force to remove large size carbon dust. It is prevent filters from clogging with dust particles. The helium contained carbon dust is called dust-laden. The dust laden enters cyclone through coolant inlet and is diverted by a helical baffle. The dust particle size distribution from the inlet and outlet of F2 is seen in Table 5 and Figure 8. Centrifugal force moves the heavy dust to the interior sidewalls and carries them to the base of the unit which called dust hopper (stream no. 9). Clean coolant is carried through the inner cylinder and discharges (stream no. 8) to filter for next separation. The larger size of carbon dust is collected in dust hopper (stream no. 9) with more than 51\% amount of it. In the dust hopper is dominated by larger size comparing to fine particles and it clearly explains in particle size distribution of stream no. 9. The total efficiency of carbon dust removed in this simulation is $98.93 \%$ from $0.0046 \mathrm{~kg} / \mathrm{h}$ in the inlet of HPS to $0.000049 \mathrm{~kg} / \mathrm{h}$ in purified helium.

Table 5. Particle size distribution of inlet and outlet of cyclone (CS), and F1 and F2 filters

\begin{tabular}{|c|c|c|c|c|c|c|c|}
\hline \multirow[t]{2}{*}{ Parameters } & \multirow{2}{*}{$\begin{array}{l}\begin{array}{l}\text { Inlet of } \\
\text { CS }\end{array} \\
\text { Dirty } \\
\text { stream } \\
\text { (stream } \\
\text { no. 3) }\end{array}$} & \multicolumn{2}{|c|}{ Outlet of CS } & \multicolumn{2}{|c|}{ Outlet F1 } & \multicolumn{2}{|c|}{ Outlet F2 } \\
\hline & & $\begin{array}{c}\text { dust } \\
\text { hopper } \\
\text { (stream } \\
\text { no. 9) }\end{array}$ & $\begin{array}{l}\text { inlet F1 } \\
\text { (stream } \\
\text { no. } 8 \text { ) }\end{array}$ & $\begin{array}{l}\text { Removed } \\
\text { (stream } \\
\text { no.4) }\end{array}$ & $\begin{array}{l}\text { Remains } \\
\text { (stream } \\
\text { no.5) }\end{array}$ & $\begin{array}{l}\text { Removed } \\
\text { (stream } \\
\text { no.6) }\end{array}$ & $\begin{array}{l}\text { Remains } \\
\text { (stream } \\
\text { no.7) }\end{array}$ \\
\hline $\begin{array}{l}\text { Mass flow } \\
\text { rate }(\mathrm{kg} / \mathrm{h})\end{array}$ & 0.0046 & 0.0029 & 0.00169 & 0.0014 & 0.00026 & 0.00021 & 0.000049 \\
\hline \multicolumn{8}{|c|}{ Particle size distribution (weight fraction) } \\
\hline $\begin{array}{l}\text { Dust size } \\
(\mu \mathrm{m})\end{array}$ & $\begin{array}{c}\text { (stream } \\
\text { no. 3) }\end{array}$ & $\begin{array}{c}\text { (stream } \\
\text { no. 9) }\end{array}$ & $\begin{array}{c}\text { (stream } \\
\text { no. 8) }\end{array}$ & $\begin{array}{c}\text { (stream } \\
\text { no.4) }\end{array}$ & $\begin{array}{c}\text { (stream } \\
\text { no.5) }\end{array}$ & $\begin{array}{c}\text { (stream } \\
\text { no.6) }\end{array}$ & $\begin{array}{c}\text { (stream } \\
\text { no.7) }\end{array}$ \\
\hline 1.00 & 0.18919 & 0.10262 & 0.33877 & 0.29953 & 0.55806 & 0.72345 & 0.51855 \\
\hline 2.00 & 0.13514 & 0.10451 & 0.18805 & 0.18604 & 0.19925 & 0.16614 & 0.20716 \\
\hline 3.00 & 0.13514 & 0.12536 & 0.15202 & 0.15866 & 0.11491 & 0.06835 & 0.12603 \\
\hline 5.00 & 0.13514 & 0.15233 & 0.10542 & 0.11497 & 0.05203 & 0.02021 & 0.05964 \\
\hline 6.00 & 0.13514 & 0.16159 & 0.08943 & 0.09876 & 0.03726 & 0.01222 & 0.04324 \\
\hline 7.00 & 0.13514 & 0.16906 & 0.07652 & 0.08534 & 0.02721 & 0.00762 & 0.03189 \\
\hline 10.00 & 0.13514 & 0.18452 & 0.04980 & 0.05669 & 0.01127 & 0.00201 & 0.01349 \\
\hline
\end{tabular}




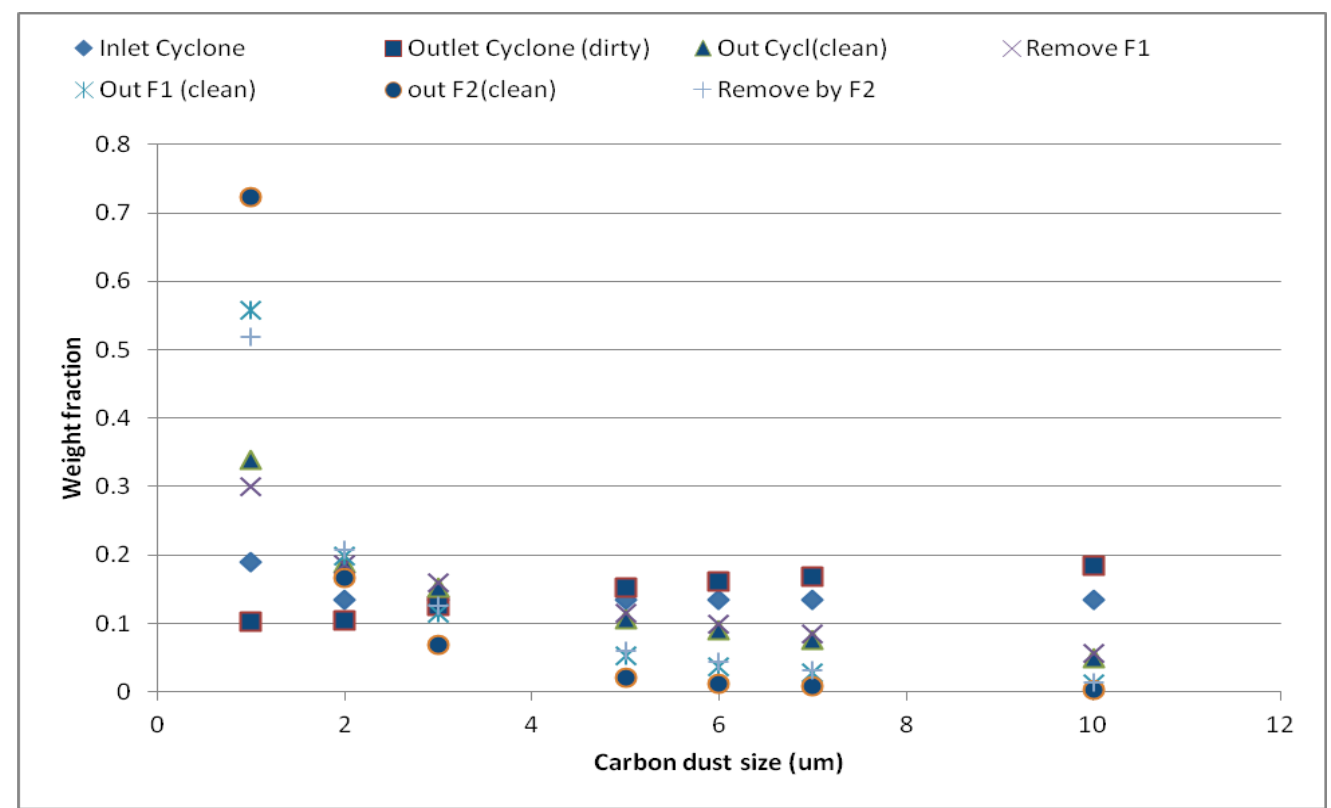

Figure 8. Particle size distribution in the inlet and outlet of Cyclone, F1 and F2 filters

The simulation results of three models showed different efficiency were achieved as seen in Figure 9. The biggest efficiency is $98.98 \%$ obtained from model using cyclone and double filters. The HTGR operation experiences indicated possibility of coarse dust $(>10 \mu \mathrm{m})$ in the primary coolant, therefore addition of cyclone to HPS is necessary. Cyclone can prevent filter blockage and prolong filter lifetime.

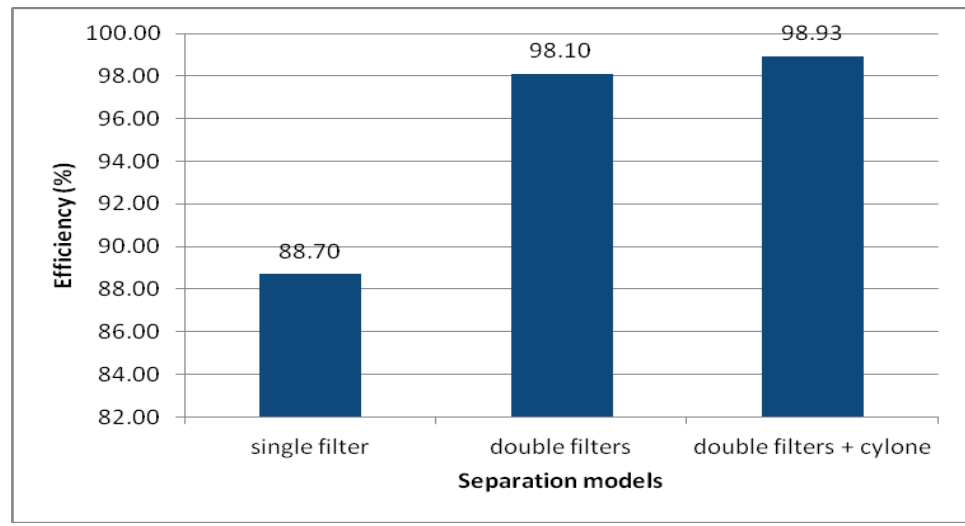

Figure 9. Dust separation models vs. efficiency

\section{CONCLUSION}

The simulation of carbon dust separation of primary coolant RDE has been done. There were 3 scenarios for dust cleaning: first scenario was using single filter, second scenario was using 2 filters and the last one was using both double filters and cyclone. The dust removal total efficiency of first model is $88.70 \%$, the second model is $98.10 \%$ and the last one is $98.89 \%$. The highest efficiency of dust removal was achieved in the model that used both double filters and cyclone. The cyclone should be installed in HPS of RDE if coarse carbon dust particle was found in primary coolant. 


\section{ACKNOWLEDGEMENT}

The author appreciate thank you very much to the Center for Nuclear Reactor Technology and Safety (PTKRN)-BATAN for the financial budget. This research is supported by BATAN annual budget of the year 2018 and also Insinas Flagship RDE Batan 2018.

\section{REFERENCES}

1. Subekti M., Bakhri S., Sunaryo G.R. The Simulator Development for RDE Reactor. J. Phys. Conf. Ser. 2018. 962(1)

2. Hamamoto S., Shimazaki Y., Furusawa T., Nemoto T., Inoi H., Takada S. Investigation of chemical characteristics of primary helium gas coolant of HTTR (high temperature engineering test reactor). Nucl. Eng. Des. 2014. 271:487-91.

3. Priambodo D., Pancoko, Sriyono M., Setiadipura T. Design of Helium Purification System for Indonesia Experimental Power Reactor- Reaktor Daya Eksperimental. Int. J. Mech. Eng. Technol. 2018. 6(7):1-7.

4. Sriyono, Kusmastuti R., Bakhri S., Sunaryo G.R. Analysis of helium purification system capability during water ingress accident in RDE. J. Phys. Conf. Ser. 2018. 962(1):1-9.

5. Peng W., Zhang T., Zhen Y., Yu S. Graphite dust resuspension in an HTR-10 steam generator. Particuology. 2014. 17:149-57.

6. Xie F., Cao J., Feng X., Liu X., Tong J., Wang H., et al. Experimental research on the radioactive dust in the primary loop of HTR-10. Nucl. Eng. Des. 2017. 324(September):372-8.

7. Humrickhouse P.W. HTGR Dust Safety Issues and Needs for Research and Development. INL/EXT-11-21097. 2011.(June)

8. Kissane M.P., Zhang F., Reeks M.W. Dust in HTRs: Its nature and improving prediction of its resuspension. Nucl. Eng. Des. 2012. 251:301-5.

9. Luo X., Wang X., Shi L., Yu X., Yu S. Nuclear graphite wear properties and estimation of graphite dust production in HTR-10. Nucl. Eng. Des. 2017. 315:35-41.

10. Natesan K., Purohit A., Tam S.W. Materials Behavior in HTGR Environments. NUREG/CR-6824. 2003.:85.

11. Peng W., Zhen Y., Yang X., Yu S. Graphite dust deposition in the HTR-10 steam generator. Particuology. 2013. 11(5):533-9.

12. Sriyono, Marliyadi P. ChemCAD Tutorial : ChemCAD Training. 2015.

13. Xie F., Cao J., Feng X., Tong J., Dong Y., Zhang Z., et al. Study of tritium in the primary loop of HTR-10: Experiment and theoretical calculations. Prog. Nucl. Energy. 2018. 105(January):99-105.

14. Pancoko M., Nugroho A., Priambodo D., Setiadipura T. Design study of a straight tube bundle steam generator for Reaktor Daya Eksperimental. IJMET. 2018. 9(5):531-40.

15. Berka J., Matcha J., Erný M., Víden I., Sus F., Hájek P. New experimental device for VHTR structural material testing and helium coolant chemistry investigation - High Temperature Helium Loop in NRI Řež. Nucl. Eng. Des. 2012. 251:203-7.

16. Zuhair, Suwoto, Setiadipura T., Bakhri S., Sunaryo G.R. Study on Characteristic of Temperature Coefficient of Reactivity for Plutonium Core of Pebbled Bed Reactor Study on Characteristic of Temperature Coefficient of Reactivity for Plutonium Core of Pebbled Bed Reactor. J. Phys. Conf. Ser. 2018. 962:012058.

17. Dibyo S., Sunaryo G.R., Bakhri S., Irianto I.D. Analysis on Operating Parameter Design to Steam Methane Reforming in Heat Application RDE. J. Phys. Conf. Ser. 2018. 962:012052. 